In-situ Monitoring of Energetic and Hydrological Performance of a Semi-Intensive Green Roof and a White Roof during a Heatwave Event in the UK

Yangang Xing ${ }^{1 \& 2^{\star}}$, Phil Jones ${ }^{2}$

1 School of Architecture, Design and the Built Environment, Nottingham Trent University, 50

Shakespeare Street, Nottingham NG1 4FQ

2 Welsh School of Architecture, Bute Building, Cardiff University, King Edward VII Ave, Cardiff CF10 3NB, UK

*Corresponding author: Dr. Yangang Xing, School of Architecture, Design and the Built Environment, Nottingham Trent University, 50 Shakespeare Street, Nottingham NG1 4FQ

Telephone: +44 1158486440

Yangang.xing@ntu.ac.uk, xygnet@hotmail.co.uk 


\section{In-situ Monitoring of Energetic and Hydrological Performance of a Semi-Intensive Green Roof and a White Roof during a Heatwave Event in the UK}

\section{Abstract}

Due to the increasing magnitude and high frequency of urban heatwaves, recently, there has been a surge of interest in the reflective roofs and the vegetative green roofs. Along with the rising temperature, there are also more frequent droughts and rainfall which have led to wider changes in weather conditions subsequently affecting the performance of green roofs and white roofs. However, there is still a lack of research in comparing dynamic energetic and hydrological performance of green roof and white roofs during heat wave events. This paper introduces a newly constructed outdoor test rig (installed with a semi intensive green roof and an aluminium white roof) and a few initial monitoring results. The hydrological performance monitoring results showed that, although a noticeable peak runoff reduction of the white roof was observed, more significant water retention of green roofs had been established. The energetic performance monitoring results indicated that the green roof performed better than the white roof during the heatwave event reducing solar heat gains by $76 \%$ during day time, improving U-Value by $28 \%$ and reducing indoor air temperature by $2.5^{\circ} \mathrm{C}$. The peak indoor air temperature reduction in the green roof space occurred during late afternoons (around $7 \mathrm{pm})$.

\section{Keywords}

Green roof, Outdoor test rig, Rainwater retention and detention, Measurement of heat flux, Dynamic U-values, Solar heat gains, Temperature gradient, Indoor thermal environment

\section{Introduction}

Due to climate change, life-threatening heat waves ${ }^{1}$ and concurrent hot and dry summers ${ }^{2}$ has been predicated to be a more common occurrence in the future. In addition, increasing magnitude and frequency of rainfall driven urban flooding have also been observed ${ }^{3}$. Global weather scientists have established and predicted that heatwaves, lasting from days to weeks, are often related to increased human mortality ${ }^{1,4}$. Nature-based solutions ${ }^{5-7}$, such as green roofs, have been proven efficient in heat 
flux reduction and rainwater retention in order to reduce urban flooding risks and urban heat island effects simultaneously ${ }^{5,6,8}$. White or bright roofs are a competing building roof technology to green roofs as a method to reduce the urban heat island effects and roof top temperatures ${ }^{9,10}$. Previous research activities compared green roof and white roofs performances ${ }^{10-12}$ demonstrate that green roofs are not only cooling primarily through albedo, but also through latent heat loss. However, there is a lack of research studying green roof thermal performance during a heat wave event when the moisture content in the green roof substrate may be very low. To make informative decisions in designing a green roof or a white roof, detailed dynamic energetic and hydrological performance need to be examined, especially during heat wave events.

To quantify energetic and hydrological performance of green roofs and white roofs is a challenging problem involving multiple parameters, such as building physics, roof albedo and characterisation of vegetation and substrates. These parameters vary significantly depending on external weather conditions. To date, two approaches have been applied in examining the energetic and hydrological performance of green roofs and white roofs, namely: (i) Computer modelling and simulation ${ }^{11,13}$; (ii) Outdoor test rig experiment ${ }^{10,14}$ or indoor controlled laboratory testing ${ }^{15}$.

As the computer simulation method is relatively easy to construct, it is now a widely used approach to study the performance of green and white roofs. For example, EnergyPlus have been used for energetic studies of both white $\operatorname{roof}^{9}$ and green roof ${ }^{13}$. However, there is a lack of robust input data for the computer simulation models ${ }^{11,16}$. For example, it is very difficult to establish physical input parameters of green roof plants ${ }^{16}$, and dynamic albedo factors of white roofs ${ }^{11}$. Furthermore, most building energy models (e.g. EnergyPlus) utilise a Conduction Transfer Function (CTF) algorithm, which is incapable of using dynamic thermal conductivity (k-value). The finite elements method, on the other hand, is computationally expensive but can only produce simulation result as a snapshot in time. Hydrological models, such as Storm Water Management Model (SWMM), can predict roof rainfall retention and detention rates. However, the lack of readily available modelling input data has prohibited these models to produce vigorous outputs ${ }^{17}$.

A number of outdoor white roof experiments have been carried out ${ }^{9,10,12}$, however, there is a lack of 
detailed research to establish dynamic thermal behaviour over time and compare their energetic and hydrological performance simultaneously with that of a green roof. Several of the existing outdoor green roof energetic test rigs have been constructed using different substrates ${ }^{14}$, different plants ${ }^{18-20}$ and different insulation layers ${ }^{21,22}$ in examination of indoor temperature reduction performance of the green roofs. These tests' results showed that green roofs reduced indoor temperatures, however, they overlooked the dynamic features of thermal conductivity (k-value), heat flux and the temperature gradient at different layers over time, which are particularly important for indoor thermal performance analysis. A few hydrological test rigs have been constructed to establish green rainfall capture rates $^{17,23}$. The results showed that a green roof system could reduce storm water runoff generation, with reported volume retention rates in the order of $40-80 \%$ of the total annual rainfall volume and the reduction of about $60 \%-80 \%$ in storm water peak runoff rates ${ }^{17,23}$. The shortcoming of these hydrological test rigs was that they did not compare with the white roof hydrological performance, and not monitor energetic performance of green roofs during heat wave events. Laboratory testing, on the other hand, can provide a well-controlled environment. However, the realistic ambient conditions (e.g. solar radiation and wind dynamics) cannot be fully replicated. In contrast, an outdoor test rig, although costly to construct, can test green roofs and white roofs in real weather conditions, particularly during extreme heatwave events. A key aim of this research is to investigate and compare dynamic features of energetic and hydrological performance of a green roof and an aluminium roof during a heatwave event in the UK. A real-cabin-size test rig was constructed, and energetic and hydrological data was collected at 5-minute intervals. The analysis of results showed that the green roof provided significant rainfall capture and reduced inward solar heat flux during the heatwave event.

\section{Construction of the Test Rig}

The experiment used a newly constructed steel frame test rig (Figure 1, 2 and 3), which was insulated with $\mathrm{U}$-value of $0.31 \mathrm{~W} / \mathrm{m}^{2} \mathrm{~K}$ for the floor and walls and $0.25 \mathrm{~W} / \mathrm{m}^{2} \mathrm{~K}$ for the south facing roof. The roof was a standing aluminium seam pitched construction with a 5-degree angled slope. A semi-intensive green roof (wildflower mat) was installed utilising a ladder tower shown as in Figure 3(a). A geocomposite filter layer (Figure 3(b)) was installed on standing seam metal roofs providing a lightweight drainage layer and a water reservoir to sustain plant growth. The geo-composite filter layer was 
Indoor and Built Environment, DOI: 10.1177/1420326X19887218

https://journals.sagepub.com/doi/full/10.1177/1420326X19887218

wrapped over a perforated cuspated HDPE (High Density Polyethylene) core using recycled polymers. The depth of the substrate was $150 \mathrm{~mm}$ with $20 \%$ settlement factor. The Wildflower Mat (Blackdown $®$ ) was $20 \mathrm{~mm}$ thick pre-grown wildflowers, grasses and herbal blankets (Figure 3(c)). The green roof substrates consisted of $80 \%$ crushed bricks and $20 \%$ composts. The test rig has two thermally isolated test chambers divided by an insulated partition wall with $\mathrm{U}$-value of $0.33 \mathrm{~W} / \mathrm{m}^{2} \mathrm{~K}$ to compare the indoor temperatures of two chambers with and without the green roof installation (Figure 3(d)). Each chamber had a $3.6 \mathrm{~m}^{2}$ indoor floor area with an average $2.5 \mathrm{~m}$ celling height, which resulted in a $9 \mathrm{~m}^{3}$ internal air volume.
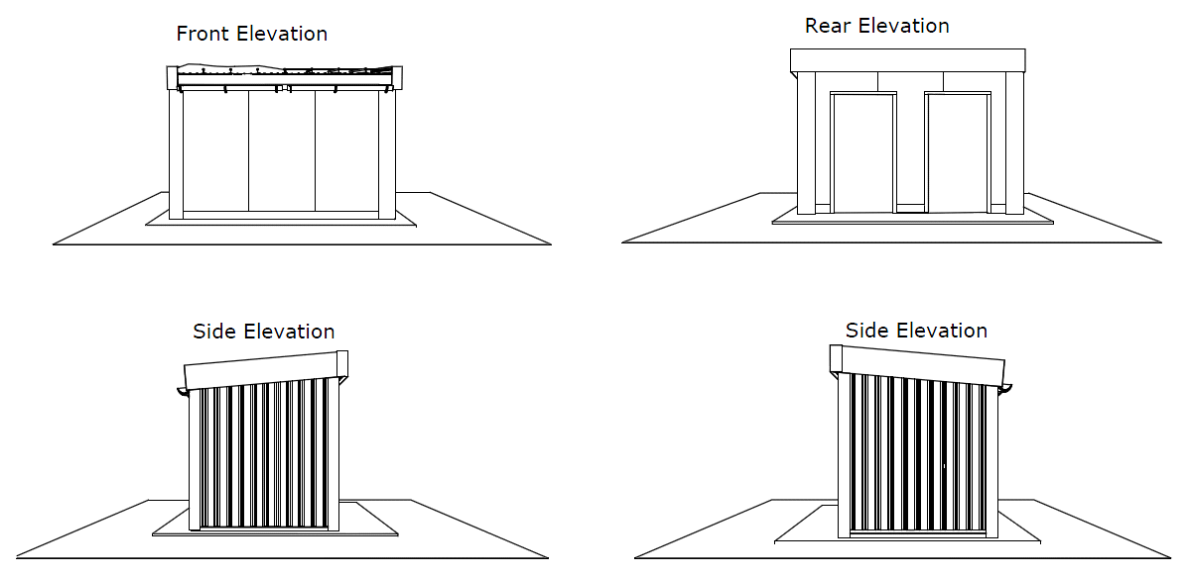

Figure 1. Four Exterior Elevations of the Test Rig 
Indoor and Built Environment, DOI: 10.1177/1420326X19887218

https://journals.sagepub.com/doi/full/10.1177/1420326X19887218

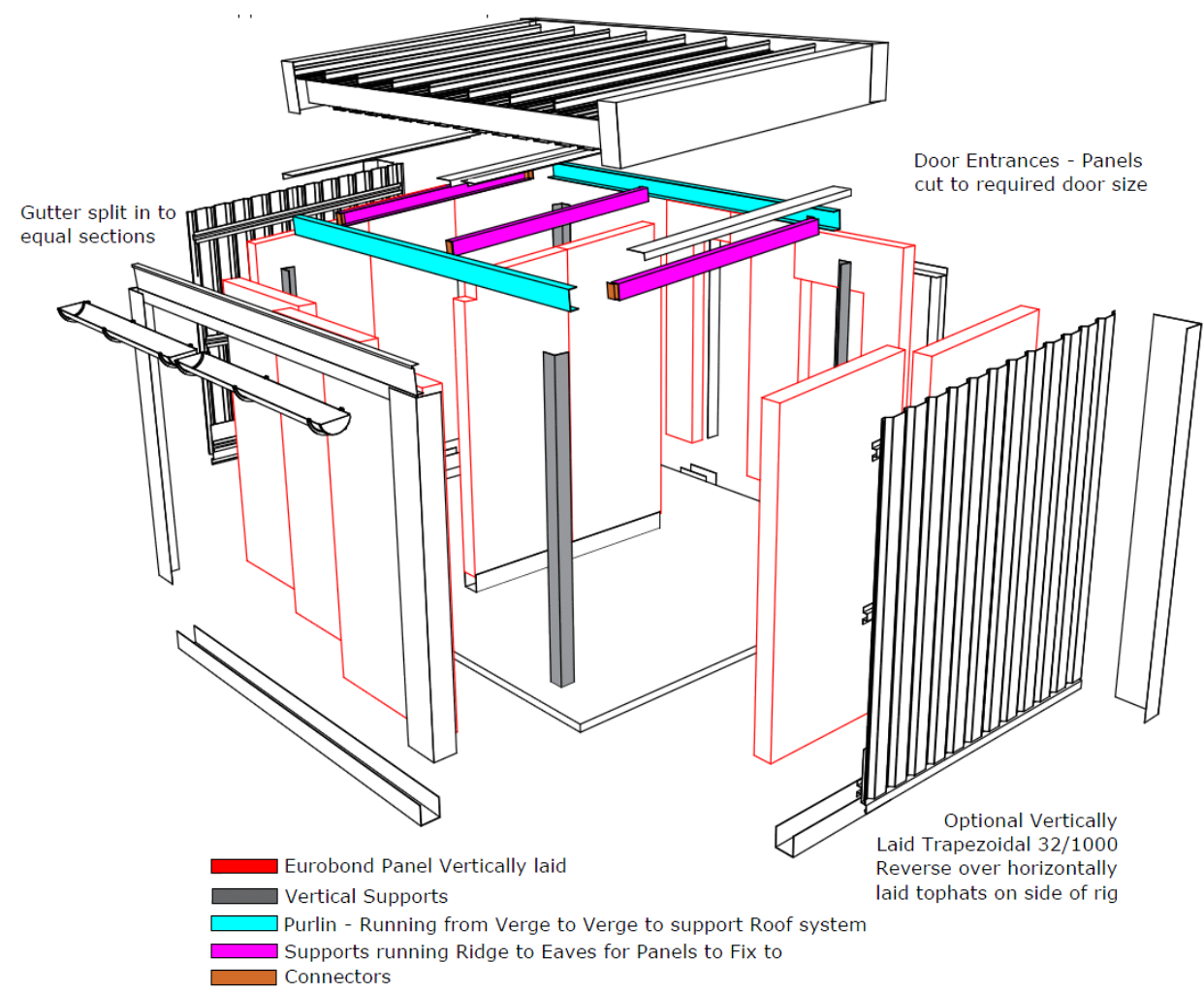

Figure 2. Visual Representations from the Front Elevation

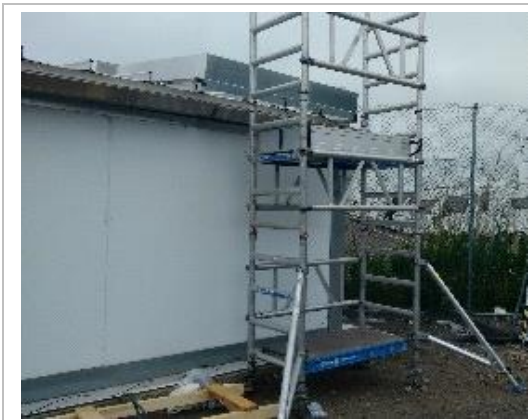

3(a) Installation a ladder tower

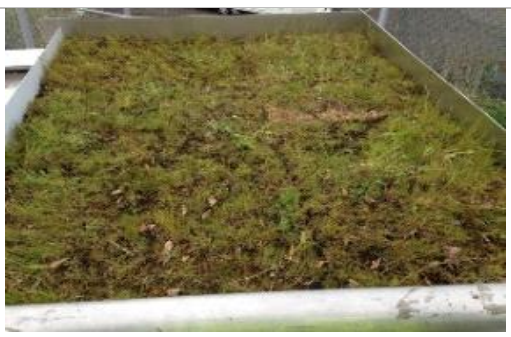

3(c) The green roof as installed

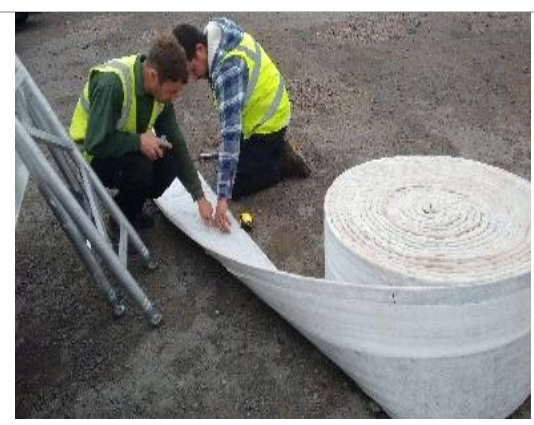

3(b) Cutting the drainage layer

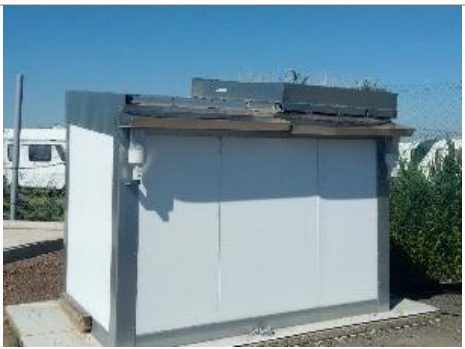

3(d) The finished test rig

Figure 3. Green Roof Installation

The test rig was set up to investigate the energetic and hydrological performance in a single holistic building framework. A range of sensors (as in Table 1, Figures 4 and 5) were installed. An Automatic 
Weather Station (WS-GP1) was installed on site near the test rig (about 3 metres away) at a similar height with the roof of the test rig. The weather station (WS-GP1) was equipped with a rain-gauge RG2, solar radiation sensors, and sensors measuring wind speed, wind direction, relative humidity and air temperature. In total eight temperature sensors (Table 1) were used, including:

- one for the indoor air temperature located in the middle of each indoor chamber room,

- one for the ceiling surface temperature fixed to the middle of each chamber roof celling,

- two for the bare aluminium roof surface (on the two middle panels of the roof as in Figure 5(a)),

- two for the bottom layer green roof substrate, and two heat flux plates measured the heat flux through the green roof substrates (on the two middle panels of the roof as in Figure 5(b)),

- two soil moisture and temperature probes were installed (buried above the two middle panels of the green roof as in Figure 5(c))

- two for the green roof surface layer temperatures (above on the two middle panels of the green roof as in Figure 5(d)).

- two rain-gauges (RG2) installed to measure the runoffs from the green roof and the bare aluminium roof (as in Figure 3(d)).

Delta-t GP2 dataloggers were used and the data were recorded at 5-minute intervals and were accessible on a cloud server through a GPRS system.

\begin{tabular}{|c|c|c|c|c|c|}
\hline & Measure & Sensors & Units and Locations & Resolutions & Accuracy \\
\hline 임 & $\begin{array}{l}\text { Air and } \\
\text { surface } \\
\text { Temperature }\end{array}$ & $\begin{array}{l}2 \mathrm{k} \\
\text { thermistor } \\
\text { Delta-T } \\
\text { ST1 }\end{array}$ & $\begin{array}{l}+ \text { Two at bare roof surface, Figure } \\
5 \text { (a) } \\
+ \text { Ceiling and air in each cabin (total } \\
4 \text { units) } \\
+ \text { Two sets (at the bottom and the } \\
\text { top green roof layer, total } 4 \text { units), } \\
\text { Figure } 5 \text { (b\&d) }\end{array}$ & $0.5^{\circ} \mathrm{C}$ & $\pm 0.2^{\circ} \mathrm{C}$ \\
\hline & $\begin{array}{l}\text { Heat flux } \\
\text { plate }\end{array}$ & HFP 01 & $\begin{array}{l}\text { Two HFP01, Figure } 5(\mathrm{~b}) \text {, in the } \\
\text { bottom of the green roof }\end{array}$ & $\mu \mathrm{v} /\left(\mathrm{W} / \mathrm{m}^{2}\right)$ & $\begin{array}{l}-15 \% \text { to } \\
+5 \%\end{array}$ \\
\hline 8 & $\begin{array}{l}\text { Soil Moisture } \\
\text { and } \\
\text { temperature }\end{array}$ & $\begin{array}{l}\text { ML3 } \\
\text { Delta-T }\end{array}$ & $\begin{array}{l}\text { Two ML3, Figure } 5(\mathrm{c}) \text {, in the middle } \\
\text { layers of the substrates }\end{array}$ & $\begin{array}{l}\text { Moisture } \\
0.1 \% \\
\text { Temperature } \\
0.5^{\circ} \mathrm{C} \\
\end{array}$ & $\begin{array}{l}\text { Moisture } \\
\pm 2 \% \\
\text { Temperatu } \\
\text { re } \pm 0.2^{\circ} \mathrm{C}\end{array}$ \\
\hline 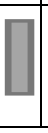 & $\begin{array}{l}\text { Runoff flow } \\
\text { meter }\end{array}$ & $\begin{array}{l}\text { Raingauge } \\
\text { Delta-T } \\
\text { RG2 }\end{array}$ & $\begin{array}{l}\text { Two RG2 at each downpipe end of } \\
\text { green roof and bare roof, Figure } \\
\text { 3(d) }\end{array}$ & $\begin{array}{l}0.2 \mathrm{~mm} \text { per } \\
\text { tip }\end{array}$ & $\pm 2 \%$ \\
\hline
\end{tabular}

Table 1. Sensors details 
Figure 4. Monitoring Plan

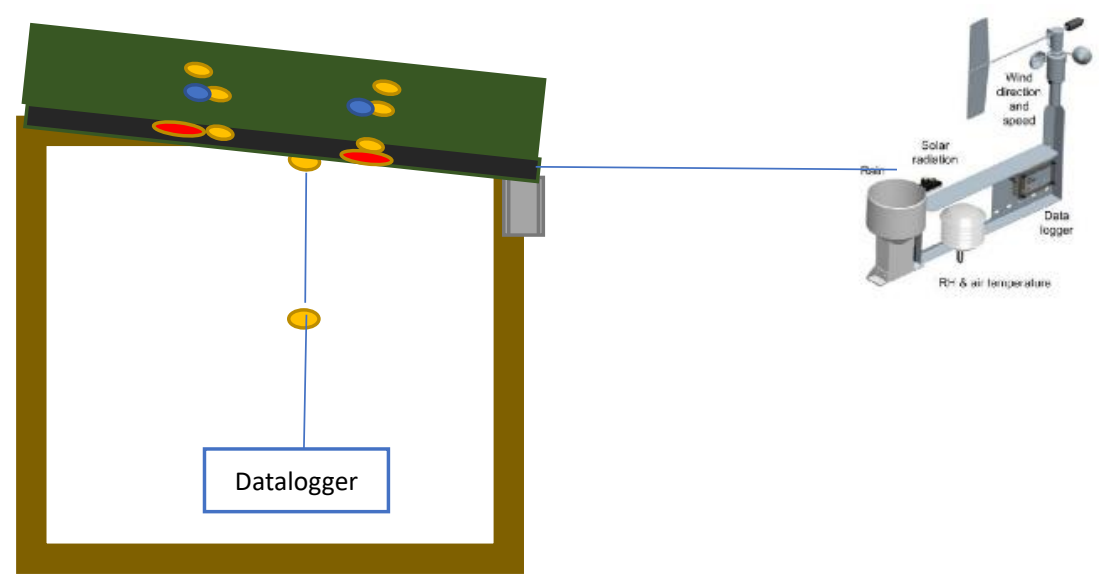

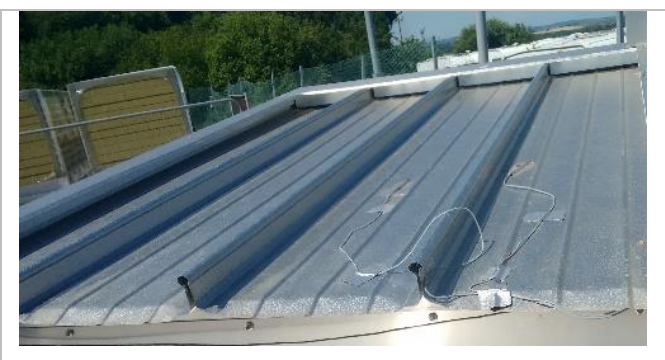

5(a) Surface temperature sensors

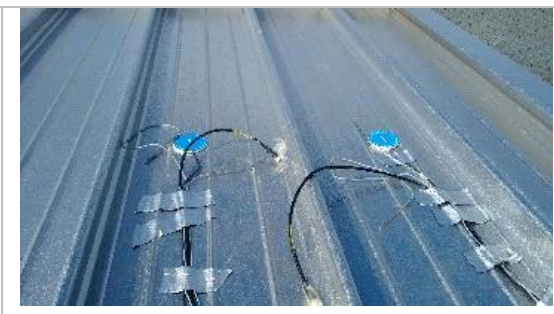

5(b) HFP01 and thermistors (preinstallation of the green roof)

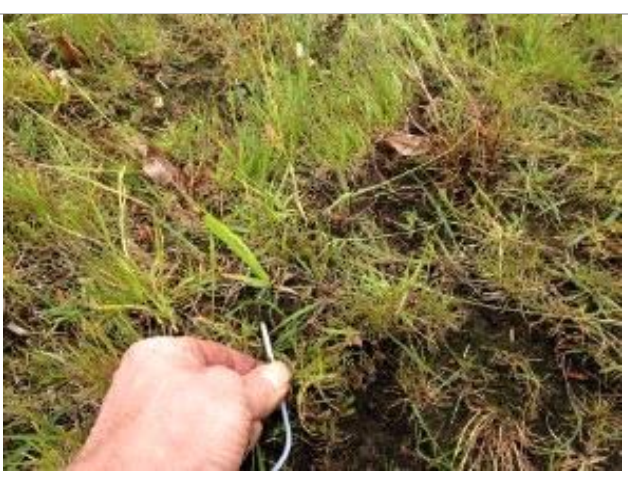

5(d) Inserted thermistors into the top layer of soil 5(c) Buried ML3 moisture and temperature sensors (pre- installation of the green roof)

Figure 5. Installation of Sensors 
Indoor and Built Environment, DOI: 10.1177/1420326X19887218

https://journals.sagepub.com/doi/full/10.1177/1420326X19887218

Results

The heatwave weather conditions during this experiment

The experiment was carried out in the Summer of $2018\left(31^{\text {st }}\right.$ May to $30^{\text {th }}$ June 2018$)$ when an unusually prolonged heatwave occurred in the UK, and the heatwave intensified towards the end of the monitoring period (Figure 6(a)). Unusually high air temperatures, global solar radiation (Figure 6(a)) and scarce rainfall were recorded (Figure 6(b)). According to historical data (1981-2010), the total rainfall, the average temperature and the maximum temperature in June between 1981-2010 were $66.6 \mathrm{~mm}, 11.0^{\circ} \mathrm{C}$ and $19.8^{\circ} \mathrm{C}$ respectively ${ }^{24}$. However, in June 2018 the monitored readings provided by an on-site automatic weather station WS-GP1 were $3.6 \mathrm{~mm}, 17.7^{\circ} \mathrm{C}$ and $29^{\circ} \mathrm{C}$. The hot and dry weather condition led to a very low volumetric water content (VWC) of the green roof (below $2 \%$ towards the end of the monitoring period as in Figure $6(b))$.

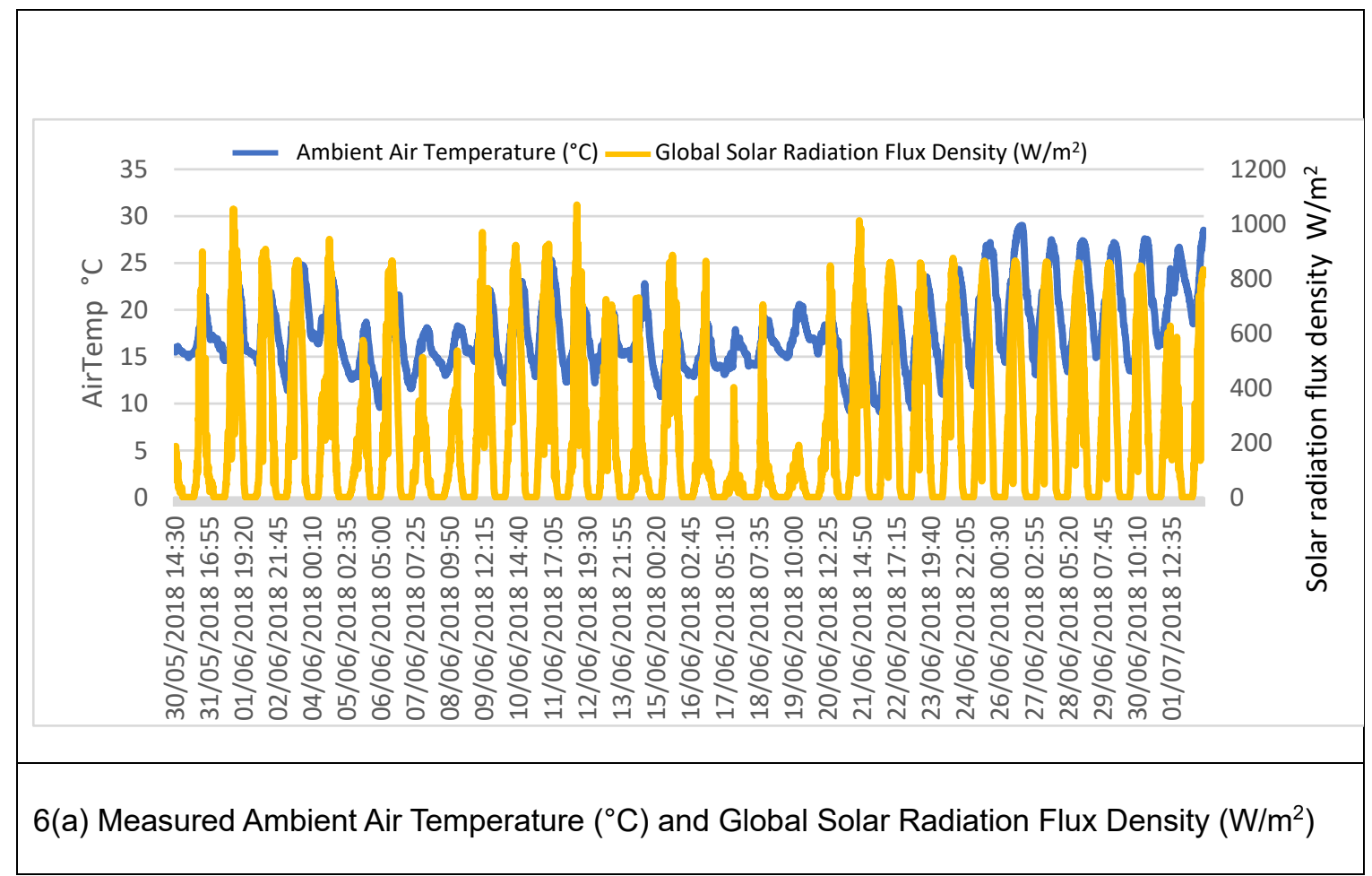


Indoor and Built Environment, DOI: 10.1177/1420326X19887218

https://journals.sagepub.com/doi/full/10.1177/1420326X19887218

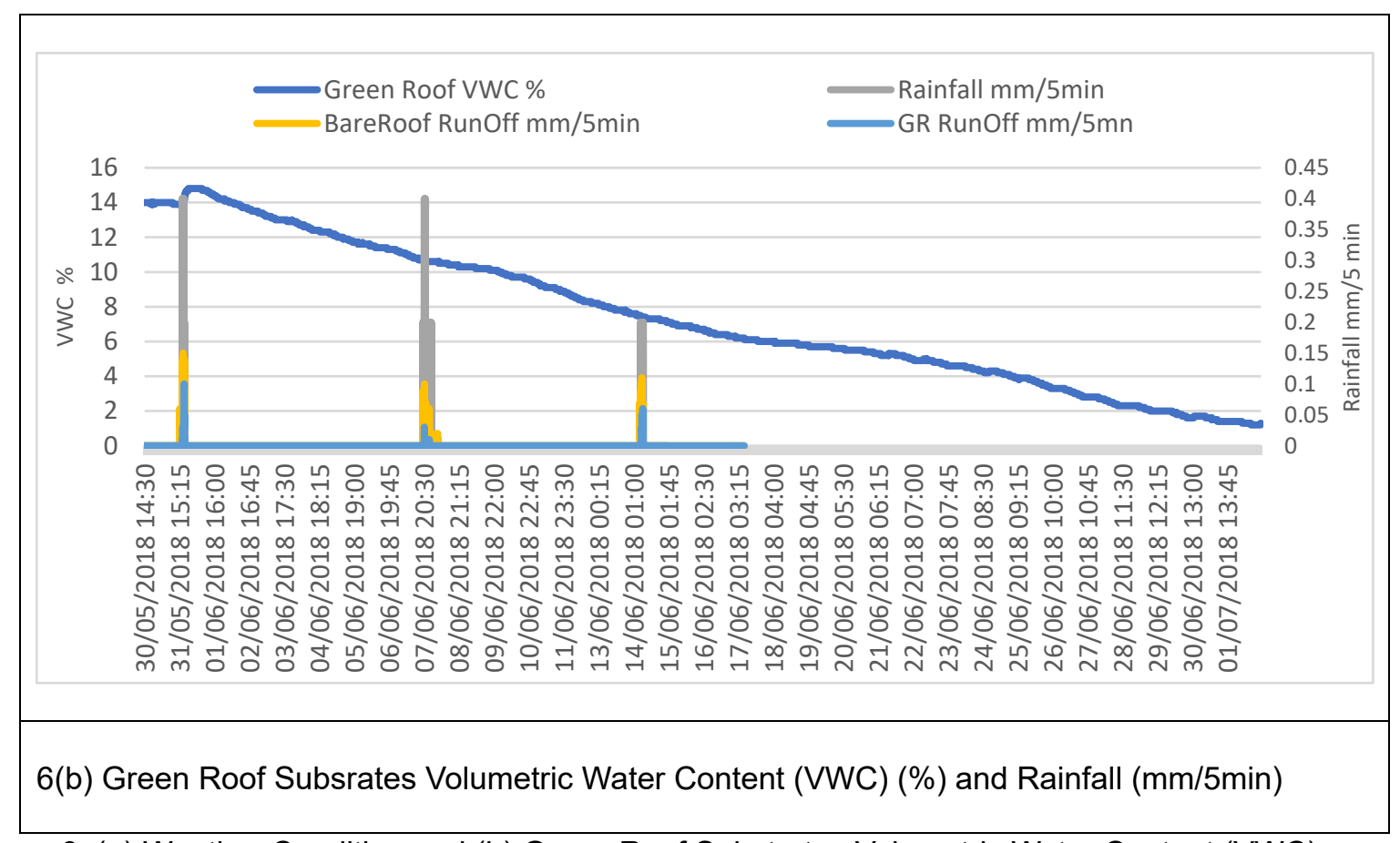

Figure 6. (a) Weather Condition and (b) Green Roof Substrates Volumetric Water Content (VWC)

\section{Hydrological performance}

Retention is considered as a permanent water removal (e.g. water evaporated to the air above the roof). The retention of rainwater at any given time is the evaporation volume for a bare aluminium roof, and it is a sum of the evapotranspiration and the water currently stored in the growing medium for a green roof ${ }^{17,23}$. The retention rate was calculated by Equation $(1)^{17,23}$ :

Retention Rate $(\%)=\frac{\text { Rainfall }(\mathrm{mm})-\operatorname{Runoff}(\mathrm{mm})}{\operatorname{Rainfall}(\mathrm{mm})} X 100$,

On the other hand, the detention capacity (usually calculated as peak flow reduction) is the ability to attenuate and delay peak flows. The peak flow reduction rate was determined by Equation $(2)^{17,23}$ :

Peak Flow Reduction Rate $(\mathrm{mm})=\frac{\text { Maximum Railfall }(\mathrm{mm})-\text { Runoff Peak Flow }(\mathrm{mm})}{\text { Maximum Railfall }(\mathrm{mm})} X 100$,

During the monitoring period of ( $31^{\text {st }}$ May to $30^{\text {th }}$ June 2018), only three rainfall events were observed (Figure $6(\mathrm{~b})$ ). From $31^{\text {st }}$ May to $30^{\text {th }}$ June 2018 , a total of only $7.8 \mathrm{~mm}$ rainfall occurred. Utilising 
Equation (1) and Equation (2), the observed rainfall retention rates had a range of $64.29 \%$ to $93.13 \%$ for the green roof and a range of $11.50 \%$ to $61.88 \%$ for the bare aluminium roof (as shown in Table 2 , Figure 7 and Figure 8). The peak flow reduction rates were $65 \%$ to $90 \%$ for the green roof and $40 \%$ to $65 \%$ for the bare aluminium roof (as shown in Table 2). The green roof had better water retention and peak flow reduction than the bare aluminium roof. The bare aluminium roof had the lowest water retention rate (11.5\%) during Event 3 (between 5.50am and $7.55 \mathrm{am}$ ) due to the lower evaporation rate, attributed to the lower density of the solar radiation and lower bare aluminium roof temperature during early morning. In the same event 3 , the green roof, on the other hand, showed much higher water retention rate $(73.5 \%)$ due to the lower water content in the substrates during the same event.

\begin{tabular}{|c|c|c|c|c|}
\hline \multicolumn{2}{|c|}{$\begin{array}{r}\text { Rain Event } \\
\end{array}$} & 1 & 2 & 3 \\
\hline \multicolumn{2}{|r|}{ Rainfall Time and Duration } & $\begin{array}{l}31 / 05 / 2018 \\
16: 00-20: 30\end{array}$ & $\begin{array}{l}\text { 07/06/2018, } \\
20: 40-22: 35\end{array}$ & $\begin{array}{l}\text { 14/06/2018, } \\
5: 50-7: 55\end{array}$ \\
\hline \multirow{5}{*}{$\begin{array}{l}\text { Rainwater } \\
\text { Retention }\end{array}$} & Total rain fall $\mathrm{mm}$ & 4.2 & 1.6 & 2 \\
\hline & Total Runoff Bare Roof mm & 2.12 & 0.61 & 1.77 \\
\hline & Retention Rate \% - Bare roof & $49.52 \%$ & $61.88 \%$ & $11.50 \%$ \\
\hline & Total Runoff Green Roof mm & 1.5 & 0.11 & 0.53 \\
\hline & Retention Rate \% - Green roof & $64.29 \%$ & $93.13 \%$ & $73.50 \%$ \\
\hline \multirow{7}{*}{$\begin{array}{l}\text { Peak Flow } \\
\text { Reduction }\end{array}$} & Peak rainfall $\mathrm{mm} / 5 \mathrm{~min}$ & 0.4 & 0.4 & 0.2 \\
\hline & Peak runoff bare roof $\mathrm{mm} / 5 \mathrm{~min}$ & 0.15 & 0.14 & 0.12 \\
\hline & $\begin{array}{l}\text { Peak flow reduction bare roof, } \mathrm{mm} / 5 \\
\text { min }\end{array}$ & 0.25 & 0.26 & 0.08 \\
\hline & Peak Flow Reduction \% - Bare roof & $62.50 \%$ & $65.00 \%$ & $40.00 \%$ \\
\hline & Peak runoff green roof $\mathrm{mm} / 5 \mathrm{~min}$ & 0.1 & 0.04 & 0.07 \\
\hline & $\begin{array}{l}\text { Peak flow reduction Green roof } \mathrm{mm} / 5 \\
\text { min }\end{array}$ & 0.3 & 0.36 & 0.13 \\
\hline & Peak Flow Reduction \% - Green roof & $75.00 \%$ & $90.00 \%$ & $65.00 \%$ \\
\hline
\end{tabular}

Table 2. Water Retention and Peak Flow Reduction Rates 
Indoor and Built Environment, DOI: 10.1177/1420326X19887218

https://journals.sagepub.com/doi/full/10.1177/1420326X19887218

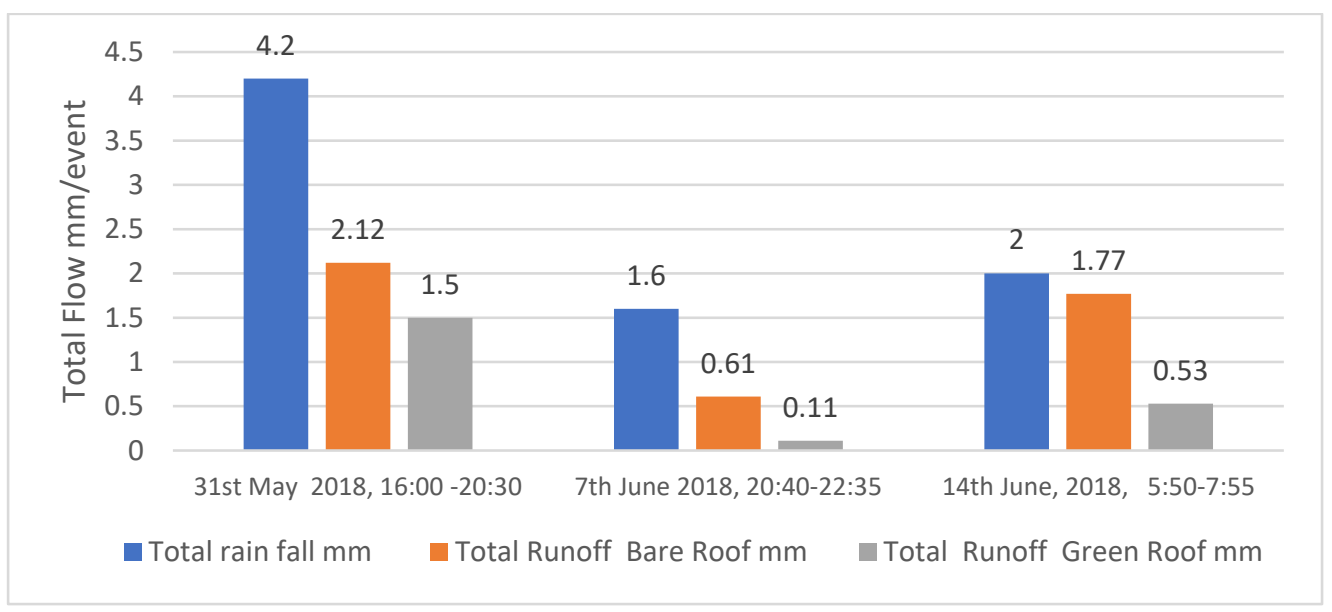

Figure 7. Rainwater Retention Performance

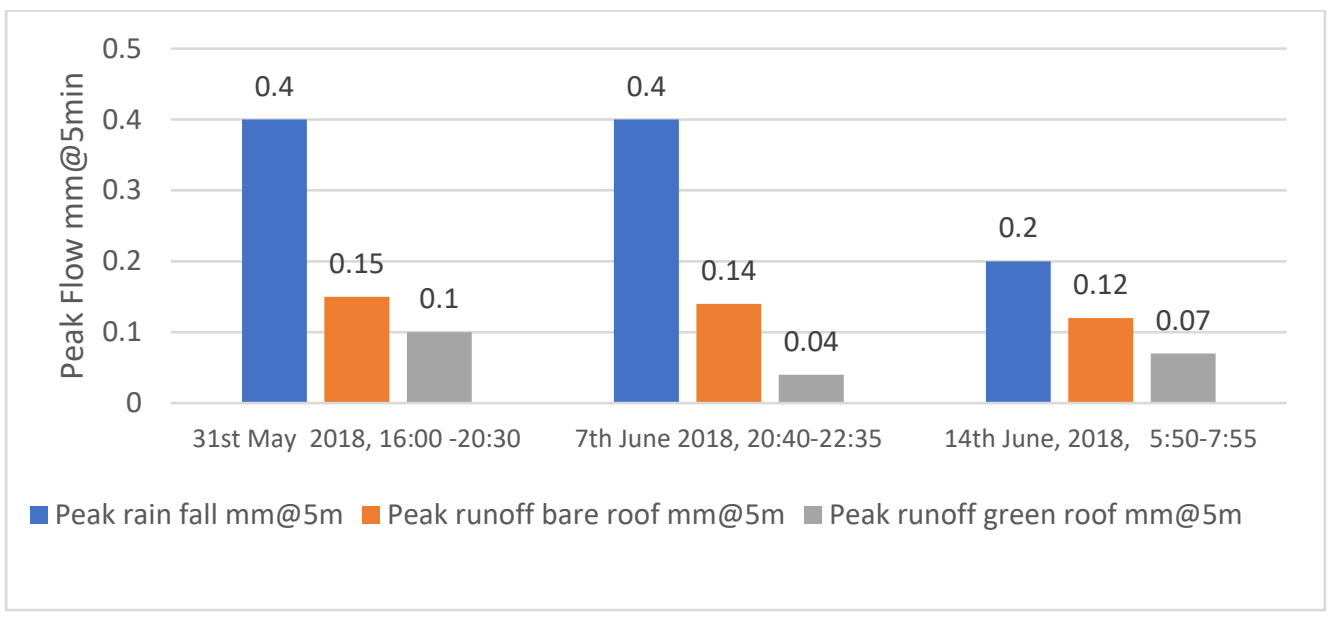

Figure 8. Peak Flow Reduction - Rainwater Detention Performance

Temperature gradients - indoor temperatures

Many people spend most of the time indoor, therefore, indoor temperature reduction in summer may be a key assessment criterion for building design. In this experiment, two temperature sensors $(2 \mathrm{k}$ thermistor Delta T ST1) were installed in each chamber to monitor indoor air and ceiling temperatures (Figure 4). The monitoring results showed that the green roof reduced indoor temperatures noticeably compared to the bare roof (Figure 9(a)). An average daily temperature profile showed that the peak indoor air temperature reduction occurred during late afternoons around 7pm (Figure 9(b)). On average, maximum and minimum temperature reductions during this monitoring period are presented in Table 3. The peak ceiling temperatures and air temperatures were reduced by $2.5^{\circ} \mathrm{C}$ and $2.3^{\circ} \mathrm{C}$ respectively. 


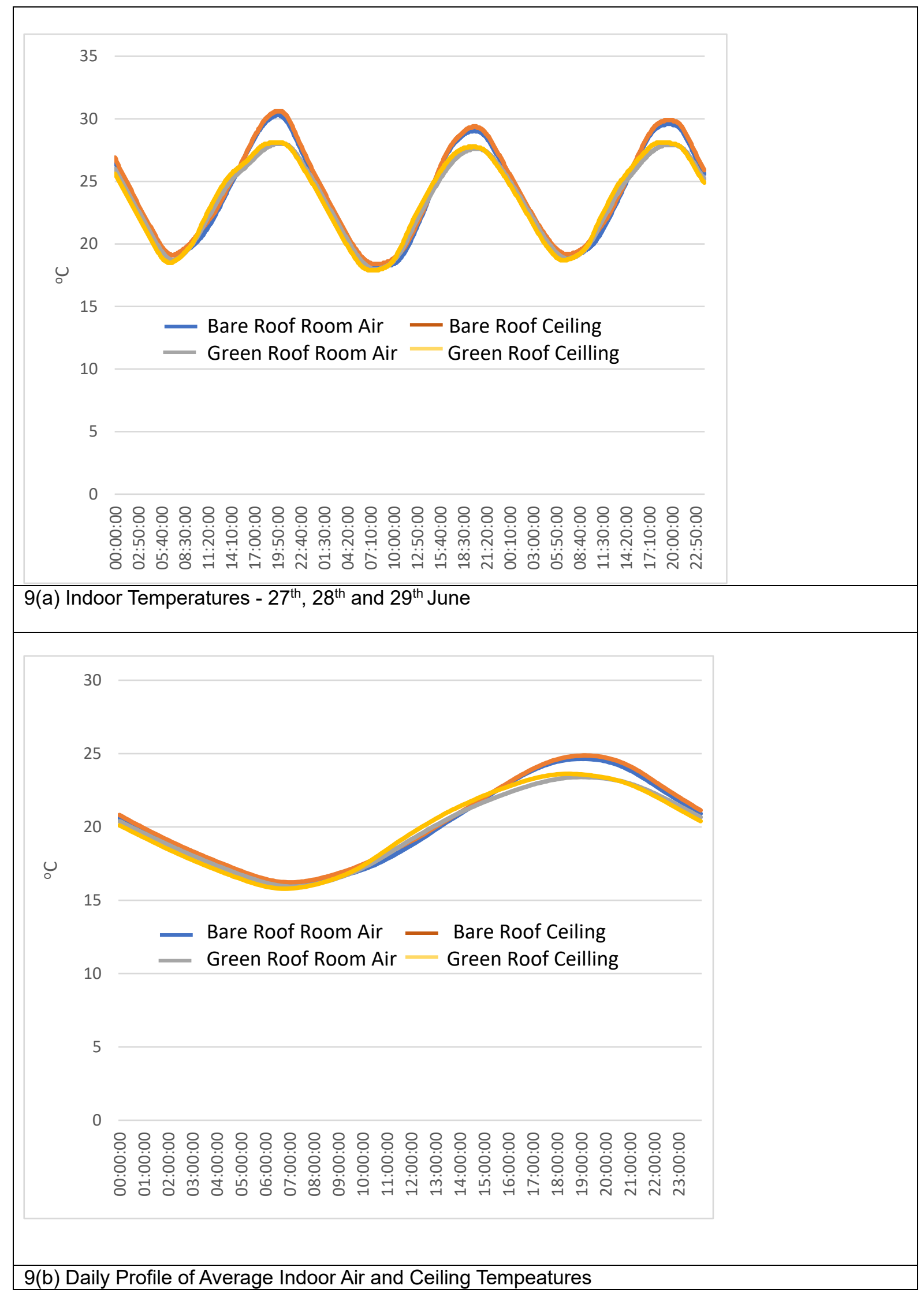

Figure 9. Indoor Temperatures 


\begin{tabular}{|l|r|l|l|l|l|l|}
\hline & \multicolumn{3}{|c|}{ Ceiling temperature ${ }^{\circ} \mathrm{C}$} & \multicolumn{3}{|c|}{ Air temperature ${ }^{\circ} \mathrm{C}$} \\
\hline & \multicolumn{1}{|c|}{ Average } & \multicolumn{1}{l|}{ Max } & \multicolumn{1}{l|}{ Min } & \multicolumn{1}{l|}{ Average } & \multicolumn{1}{l|}{ Max } & \multicolumn{1}{l|}{ Min } \\
\hline Bare Roof Chamber & 20.29 & 32.50 & 12.60 & 20.09 & 32.10 & 12.60 \\
\hline Green Roof Chamber & 19.83 & 30.00 & 12.00 & 19.79 & 29.80 & 12.30 \\
\hline Temperature Difference $^{*}$ & 0.47 & 2.50 & 0.60 & 0.31 & 2.30 & 0.30 \\
\hline
\end{tabular}

${ }^{*}$ Temperature difference $=$ BareRoof Chamber Tempeatures - Green Roof Chamber Tempeatures

Table 3. Indoor Temperature Differences

\section{Temperature gradients - roof surface temperatures}

Two surface temperature sensors (Delta T ST1) fixed on the aluminium roof, and two sets of 3-layers (top surface, middle soil and bottom under soil layer) of soil temperature sensors (Delta T ST1) were installed in the green roof substrates (Table 1). The temperatures at 8 monitoring points showed that the soil temperatures (middle soil and bottom under soil layer) were comparably stable (shown as in a sample day - Figure 10(a), whereas the aluminium and the soil surface temperatures fluctuated through a wide range reaching typical peak values of 50 to $60^{\circ} \mathrm{C}$ and $70^{\circ} \mathrm{C}$. The roof temperature gradients further revealed that the green roof substrate (middle and bottom layers) temperatures were lower than roof surface temperatures during daytime but higher during night time. The average daily profile (Figure 10(b)) showed that the temperature of the under the green roof substrate layer was lower than the bare aluminium roof surface temperature during daytime (between 8 am to $7 \mathrm{pm}$ ), the maximum difference of around $15^{\circ} \mathrm{C}$ occurred around middays; and higher during night time (between $7 \mathrm{pm}$ to $8 \mathrm{am}$ ), and the maximum difference of around $7^{\circ} \mathrm{C}$ occurred between midnights and early mornings around $5 \mathrm{am})$. 


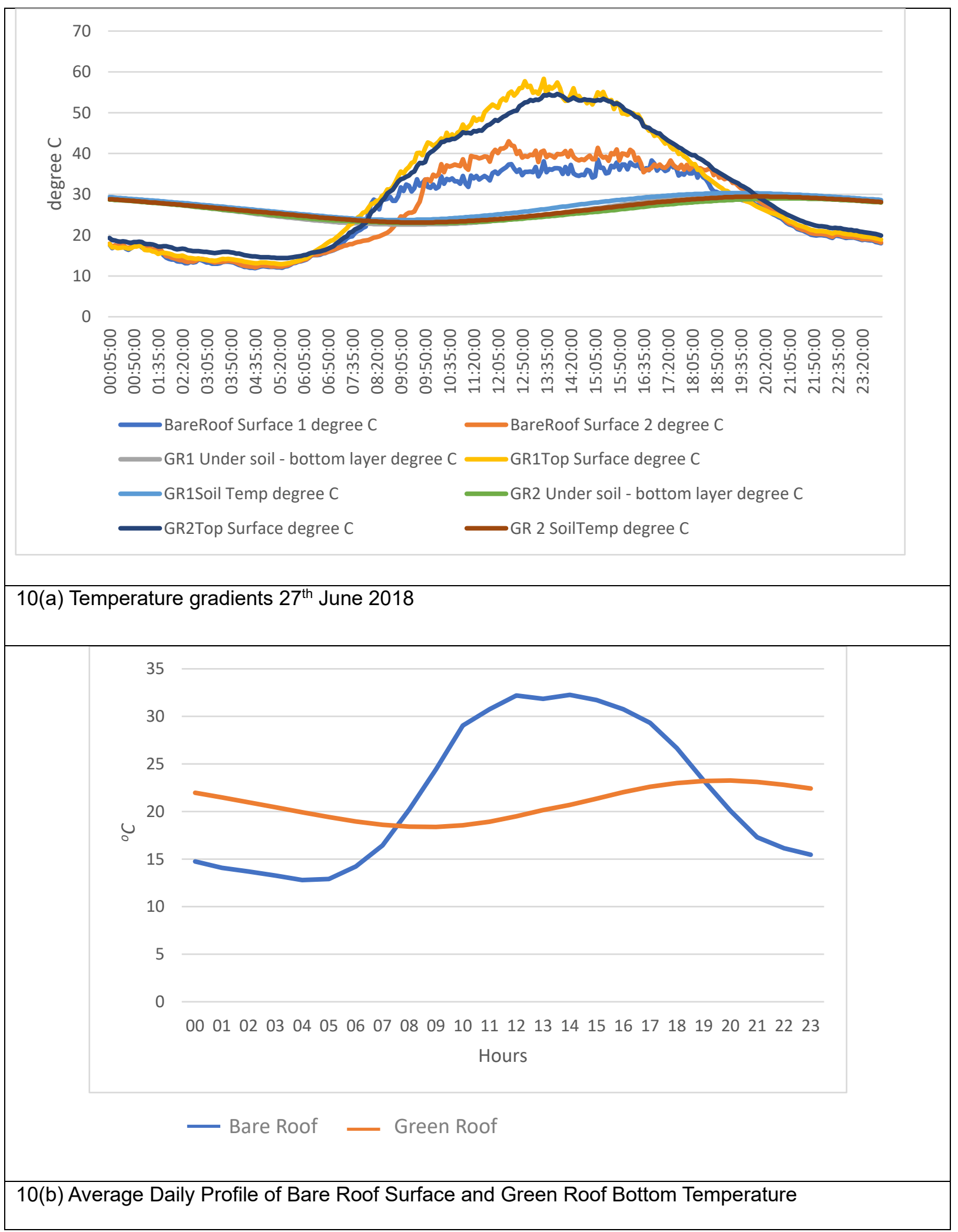

Figure 10. Average Daily Profile of Bare Roof Surface and Green Roof Bottom Temperature

The green roof was observed to have a higher surface temperature than the aluminium roof during certain periods of the time (Figure 10(a)). The surface temperatures were determined by the roof 
energy balance phenomena.

The energy balance of a green roof is dominated by radiative force from the sun and associated long wave heat exchange with surrounding environment and the sky ${ }^{25}$. Roof surface absorption of incoming solar radiation, and the long and short-wave reflection plus long wave emission exchange depending on the characterisation of the surface materials (e.g. albedo). Albedo is a reflection coefficient that describes the amount of solar radiation reflected by the surface. There is a negative correlation between the albedo effect and the surface temperature: the greater the albedo, the lower the surface temperature ${ }^{26}$. The aluminium coated roof has been reported to have an albedo of $30 \%$ $55 \%{ }^{26}$. Without regular cleaning, the albedo may decrease due to the deposits of dirt on the roof surface. Since plants have generally higher albedo than dark bare soil. The albedo of green roofs depends on the plant coverage and substrate water content: the higher the plant coverage, the higher the albedo; and also the higher the water content, the lower the albedo ${ }^{27}$. Greater variation of green roof albedo has been reported at $23 \%{ }^{28}$ and $6.6 \%{ }^{29}$, which is generally lower than reported albedo of aluminium coated roof $30 \%-55 \%{ }^{26}$. The lower albedo factor can partially explain why the recorded green roof surface temperatures were higher than the aluminium roof surface temperature during the drier period. Another contribution factor was the lack of evapotranspiration heat losses of the green roof. During the first four days of the monitoring period when the green roof was relative wet (VWC was between $10 \%-15 \%$ ), the green roof surface temperatures were lower than the aluminium roof surface temperatures. This observation is supported by the fact that apart from the solar reflection, the solar radiation is also balanced by sensible (convection) and latent (evaporative) heat flux. The evapotranspiration heat losses may have played a key role in reducing green roof surface temperature.

\section{Thermal conductivity as a function of saturate levels of the green roof substrates}

The saturation levels of green roofs substrates affect thermal conductivity significantly, however, this is difficult to establish due to complex characterisation of the substrate composition, e.g. different texture, shape of the soil and water content ${ }^{30}$. To estimate the thermal conductivity of the green roof installed on this test rig, the heat flux in the soil with accompanying temperature sensors were measured. The heat flux sensor measures heat flux through the object in which it is incorporated or on which it is mounted. The heat flux plate is a thermopile made from ceramics-plastic composite 
Indoor and Built Environment, DOI: 10.1177/1420326X19887218

https://journals.sagepub.com/doi/full/10.1177/1420326X19887218

materials to maintain a small thermal resistance. The thermopile measures the temperature difference across the sensors' ceramics-plastic composite body. The sensor was used for on-site measurement of building envelope thermal resistance per unit area ( $R$-value) and thermal transmittance ( $U$-value) according to the standardised practices of ISO 9869:part 1:2014 ${ }^{31}$ and ASTM C1155-95(2013) ${ }^{32}$.

In this experiment, two heat flux plates (HFP01) were installed, and measurement results were compared with theoretical calculations to improve the robustness of measurement results. The heat flux, $\Phi\left(\mathrm{W} / \mathrm{m}^{2}\right)$, was equal to the sensor output, a small voltage $U(\mu v)$, divided by the sensitivity $S$ $\left(\mu \mathrm{v} /\left(\mathrm{W} / \mathrm{m}^{2}\right)\right.$, which could be found on the product certificate of the sensor, as given in Equation $(3)^{33}$ :

$\Phi(W / m 2)=\frac{U(\mu v)}{S\left(\mu v /\left(\frac{w}{m 2}\right)\right)}$

The thermal conductivity (k-value) $\mathrm{W} / \mathrm{mK}$ was calculated as shown in Equation (4) ${ }^{33}$, based on the heat flux, $\Phi\left(\mathrm{W} / \mathrm{m}^{2}\right)$, the surface temperature difference, and the $L$ (depth of the substrate in metres).

$k\left(\frac{w}{m k}\right)=L(m) * \frac{\Phi(W / m 2)}{\text { TempGR Botton-TempGR Top }}$,

The measurement results showed that when the substrate's volumetric water content (VWC) was between $12 \%$ and $15 \%$ (in the first four days of the experiment), the average thermal conductivity (kvalue) of the substrate was $0.1126 \mathrm{~W} / \mathrm{mK}$. According to the HFP01 user manual ${ }^{33}$, a realistic estimate of the error range is $\pm 20 \%$ over a thermal conductivity range from (dry sand to water-saturated sand) across the temperature range of $-30^{\circ}$ to $+70^{\circ} \mathrm{C}$. The measurement result in this study was within measurement range of $0.1 \mathrm{~W} / \mathrm{mK}$ to $1.7 \mathrm{~W} / \mathrm{mK}$ detectable by heat flux plates- HFP0 $1^{33}$. The k-value established in this paper was in line with results found in other studies ${ }^{30}$. However, this experiment also observed large fluctuations of the heat flux ( $\Phi$-value). This may be attributed to the situation that the thermal parameters of ambient temperature and soil were constantly changing (e.g. soil moisture content). When the VWC was lower than $12 \%$, the k-value might be lower than $0.1 \mathrm{~W} / \mathrm{mK}$, which was out of the measurement range $(0.1 \mathrm{~W} / \mathrm{mK}-1.7 \mathrm{~W} / \mathrm{mK})$ of the heat flux plates (HFP01). In this situation an alternative steady-state measurement method, such as a guarded hot plate may be used, although 
it is suitable for a laboratory setting but not the in-situ measurement.

Thermal conductivity ( $k$-value) of green roofs can be reduced significantly by the presence of moisture within the substrates. Green roof substrates are composed of aggregate, sand and organic matter. Naturally occurring soils, on the other hand, are classified by their composition shape and texture as clay, sandy loam, silt, etc. Based on the existing models predicting thermal conductivity of soils with different saturated values, ${ }^{30,34,35}$ we have developed a simplified algorithm (as in Equation (5)) to predict seasonal thermal conductivity of green roofs.

$k=k_{D R Y} \frac{1.45 \exp (4.411 * V W C))}{1+0.45 \exp (4.411 * V W C)}$

In the Equation (5), $k$ is the predicted thermal conductivity of substrates, $k_{D R Y}$ is the thermal conductivity of dry substrates, VWC is the volumetric water content (\%). The thermal conductivity established in this experiment is a key input parameter to predict dynamic k-value with changing VWC values. Dynamic k-value of this type of green roof substrates were plotted as shown in Figure 11. Based on Equation (5), a potentially higher k-value of the green roof was calculated as $0.14 \mathrm{~W} / \mathrm{mK}$ and $0.18 \mathrm{~W} / \mathrm{mK}$ respectively (as plotted on Figure 11), when substrate volumetric water content VWC reached $30 \%$ to $50 \%$ (for typical UK winter raining seasons). The dynamic U-values of the green roof were calculated and presented in Table 4. It reached $0.18 \mathrm{~W} / \mathrm{m}^{2} \mathrm{~K}$ during the dry period, and it was calculated as $0.20 \mathrm{~W} / \mathrm{m}^{2} \mathrm{~K}$ when the green roof was saturated with VWC of $50 \%$, with $28 \%$ and $20 \%$ improvement on the $U$-value respectively compared with the bare aluminium roof alone (Table 4). In the heatwave period, additional insulation provided by the green roof reduced solar heat gain to the chamber, which is discussed in the following section "Accumulated inward solar heat gain". 


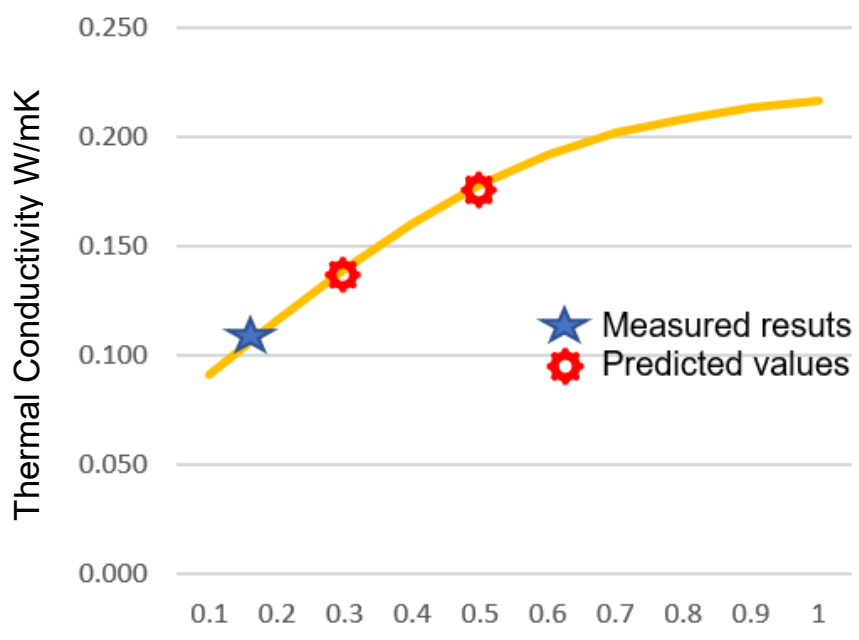

Saturation Levels of the Green Roof Substrate

Figure 11. Thermal Conductivity as a Function of Saturation Levels of the Green Roof Substrate

\begin{tabular}{|l|r|r|r|}
\hline Volumetric water content (VWC) & $12 \%$ & $30 \%$ & $50 \%$ \\
\hline $\begin{array}{l}\text { Thermal Conductivity k-value of green roof } \\
\text { (varied VWC) }\end{array}$ & $0.11 \mathrm{~W} / \mathrm{mK}$ & $0.14 \mathrm{~W} / \mathrm{mK}$ & $0.18 \mathrm{~W} / \mathrm{mK}$ \\
\hline Substrate depth & \multicolumn{3}{|c|}{$0.17 \mathrm{~m}$} \\
\hline R1-value of the green roof = depth/k & $1.54 \mathrm{~m}^{2} \mathrm{~K} / \mathrm{W}$ & $1.21 \mathrm{~m}^{2} \mathrm{~K} / \mathrm{W}$ & $0.94 \mathrm{~m}^{2} \mathrm{~K} / \mathrm{W}$ \\
\hline U-value of existing roof & \multicolumn{3}{|c|}{$0.25 \mathrm{~W} / \mathrm{m}^{2} \mathrm{~K}$} \\
\hline R2-value of existing roof =1/U-value & \multicolumn{3}{|c|}{$\mathrm{m}^{2} \mathrm{~K} / \mathrm{W}$} \\
\hline Final U-value =1/(R1+R2) & $0.18 \mathrm{~W} / \mathrm{m}^{2} \mathrm{~K}$ & $0.19 \mathrm{~W} / \mathrm{m}^{2} \mathrm{~K}$ & $0.20 \mathrm{~W} / \mathrm{m}^{2} \mathrm{~K}$ \\
\hline U-value improvement \% & $28 \%$ & $24 \%$ & $20 \%$ \\
\hline
\end{tabular}

Table 4. U-value Improvement - Impacts of Retrofitting with a Green Roof

\section{Accumulated inward solar heat gain}

The green roof can reduce inward solar heat gains as demonstrated by the green roof temperature gradients as shown in previous sections. After solar reflection, sensible and latent (evaporation) heat losses and roof insulation, only a relatively small portion of the solar heat is transferred indoors. Since there were no internal heat gain in the chambers, a simple temperature difference (TD) method was used to calculate inward solar heat gains, as in Equation (6) ${ }^{31,32}$ and Equation $(7)^{31,32 \text { : }}$

$Q_{\text {BareRroof }}=U_{\text {Roof }}{ }^{*} A_{\text {Roof }}{ }^{*}\left(T_{\text {Surface.BareRoof }}-T_{\text {Ceiling.BareRoof }}\right)$

$Q_{\text {GreenRoof }}=U_{\text {Roof }}{ }^{*} A_{\text {Roof }}{ }^{*}\left(T_{\text {BottomGreenRoof }}-T_{\text {Ceiling.GreenRoof }}\right)$ 
Where,

QBareRroof is the solar heat gain through the Bare Roof

QGreenRoof is the solar heat gain through the Green Roof

$U_{\text {Roof }}$ is the roof $U$-value

$A_{\text {Roof is }}$ the area of the roof

$T_{\text {Surface.BareRoof is the bare roof surface temperature }}$

$T_{\text {Ceiling.BareRoof is the indoor ceiling temperature in the bare roof chamber }}$

$T_{\text {BottomGreenRoof is the green roof bottom layer temperature }}$

$T_{\text {Ceiling.GreenRoof is the indoor ceiling temperature in the green roof chamber }}$

Based on Equation (6) and Equation (7), the inward solar heat gain was calculated as shown in Figure 12. Based on the average daily profile, the green roof reduced inward solar heat gains substantially from 8 am to $7 \mathrm{pm}$ (Figure 12). As shown in Table 5, the green roof, reduced total solar heat gain by $29.87 \%$ during the whole experiment; more significantly, during $8 \mathrm{am}$ to $7 \mathrm{pm}$, the heat gain was reduced by $75.87 \%$ (Table 5). The reduced solar heat gain results in lower indoor temperatures (peak indoor air temperature reduction around $2.3^{\circ} \mathrm{C}$ as shown in Table 3 ) in the green roof chamber, which then may lead to a lower cooling energy demand and improved thermal comfort, even when green roof substrates were very dry with little or non-evapotranspiration. 


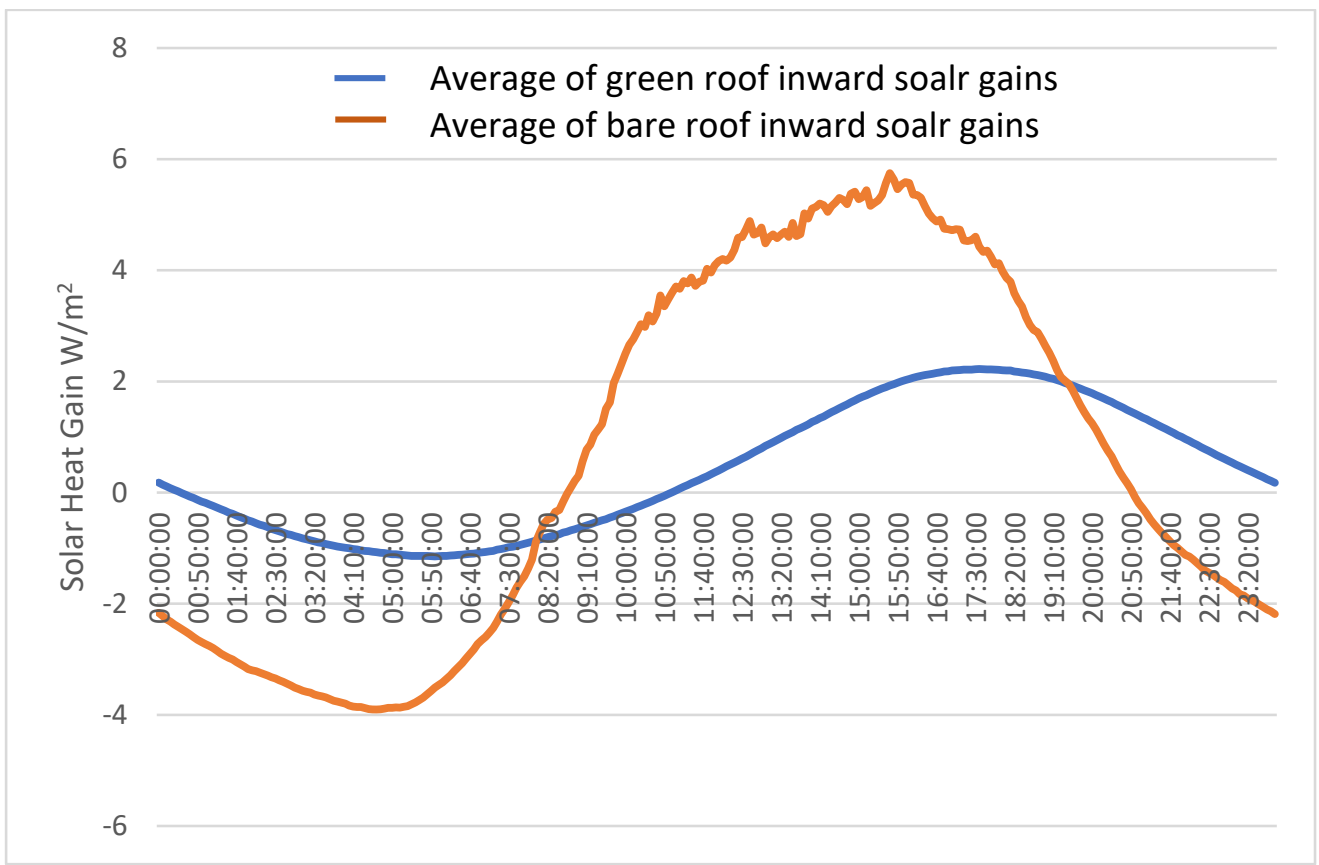

Figure 12. Daily Profile of Average Inward Solar Heat Gain

\begin{tabular}{|l|r|r|r|}
\hline & $\begin{array}{l}\text { Green Roof Gain } \\
\text { Watt-hour (Wh) }\end{array}$ & $\begin{array}{l}\text { Bare Roof Gain } \\
\text { Watt-hour (Wh) }\end{array}$ & $\begin{array}{l}\text { Solar Heat Gain } \\
\text { Reduction* }\end{array}$ \\
\hline Total & 295.60 & 421.50 & $29.87 \%$ \\
\hline 8am -7pm Only & 282.60 & $1,171.23$ & $75.87 \%$ \\
\hline
\end{tabular}

${ }^{*}$ Solar Heat Gain Reduction $=$ (Bare roof gain - Green roof gain)/ Bare roof gain

Table 5. Inward Solar Heat Gain (June 2018)

\section{Conclusions}

This paper introduced a newly constructed green roof test rig with a bare roof aluminium surface control roof for comparison. The test rig is capable of monitoring real-time energetic and hydrological performance. The initial monitoring results show that:

1) Based on the dynamic temperature performance during a heat wave period, the under-substrate layer temperature is lower than bare aluminium roof surface temperature during day time (maximum difference of around $15^{\circ} \mathrm{C}$ occurred around middays), and higher during night time (maximum difference of around $7^{\circ} \mathrm{C}$ occurred around midnights to early morning at around 5 am).

2) Peak indoor air temperature reductions are (on average daily profile): ceiling temperature by $2.5^{\circ} \mathrm{C}$ and indoor air temperature by $2.3^{\circ} \mathrm{C}$. The peak reduction is during late afternoons (at around $7 \mathrm{pm})$.

3) The green roof could significantly reduce inward solar heat gain by $75.87 \%$ between 8 am and 7 
pm with a total solar heat gain reduction of $29.87 \%$ during the whole duration of the experiment.

4) The monitoring results showed an improved U-value of $28 \%$ compared with the bare aluminium metal roof with an $\mathrm{U}$-value of $0.25 \mathrm{~W} / \mathrm{m}^{2} \mathrm{~K}$. The modelling results further indicated that when the green roof was saturated (VWC at $50 \%$ ), the U-value was still improved by $20 \%$.

The analysis indicates that the green roof would perform very well during the heatwave event and would produce effects on summertime indoor temperature reduction. In terms of water retention and detention capacities, the initial monitoring results demonstrated that:

1) The best retention and peak reduction rates of the green roof reached $93 \%$ and $90 \%$ respectively, comparing to the best retention and peak reduction rates of the bare aluminium roof which was $61.55 \%$ and $65 \%$ respectively;

2) The worst water retention rate measuring at $11.50 \%$ was observed from the bare aluminium roof, whereas it was $73.50 \%$ from the green roof in the same event.

These findings indicate that the observed retention and detention performance of the green roof are superior to the bare aluminium roof in the heatwave. This research also observed extremely low water content in the green roof substrates. During the hot dry summer, the rainwater collection may not be adequate to irrigate the green roof. Without the artificial irrigation, the plants may eventually die out and the green roof would become a "brown roof", yet it is still a nature-based urban solution ${ }^{5,36}$. "Brown roof" with deeper substrate (e.g. more than $150 \mathrm{~mm}$ ), may support re-vegetation from windblown and bird seed dispersal. However, during a drought period, irrigation can improve the energy saving capacity of a green $\operatorname{roof}^{18}$. In this situation, rainwater or grey water recycling and biodiversity, brown roof management strategy is recommended to improve the survivability and ecoservices of green roof plants and subsequently improve building thermal performance.

In this research energetic and hydrologic performance of a semi intensive green roof and an aluminium white roof were compared. The benefits of green roofs were clearly demonstrated. The test rig used in this research was adequate to generate key hydrological indicators (e.g. rainwater retention and detention rates) and energetic indicators (dynamic temperatures gradients, thermal 
conductivity and inward solar heat gain). However, there are some limitations in this experiment, for example, the relatively short monitoring period (just over one month) and the relatively small size of the test rig. A longer monitoring period and a larger in-situ monitoring site would be beneficial to establish more robust results of green roof performance during a variety of urban heat wave events. Nevertheless, the green roof test rig showed the advantages of the in-situ monitoring approach to assess the dynamic green roof performance. In the future, this green roof test rig can be potentially used to assess performance of different green roofs designs under other extreme weather conditions, and potential impacts on reducing cooling load and energy savings.

\section{Acknowledgments}

The Authors acknowledge the support of Euroclad Ltd (Wales) on construction of the test rig and financial support of the Welsh Assembly Government and Higher Education Funding Council for Wales through the Sêr Cymru National Research Network for Low Carbon, Energy and Environment.

Authors' contribution

All authors contributed equally in the preparation of this manuscript.

Declaration of conflicting interests

The authors declared no potential conflicts of interest with respect to the research, authorship, and/or publication of this article.

\section{References}

1. Mora C, Dousset B, Caldwell IR, et al. Global risk of deadly heat. Nat Clim Chang 2017; 7: $501-506$.

2. Zscheischler J, Seneviratne SI. Dependence of drivers affects risks associated with compound events. Sci Adv 2017; 3: 1-11.

3. Schreider SY, Smith DI, Jakeman A J, et al. Climate change impacts on urban flooding. Clim Change 2000; 47: 91-115.

4. WMO. Guidelines on the Definition and Monitoring of Extreme Weather and Climate Events.

Geneva: World Meteorological Organization, 2016.

5. Xing Y, Jones P, Donnison I. Characterisation of Nature-Based Solutions for the Built Environment. Sustainability 2017; 9: 149. 
Indoor and Built Environment, DOI: 10.1177/1420326X19887218

https://journals.sagepub.com/doi/full/10.1177/1420326X19887218

6. Xing $Y$, Jones $P$, Bosch $M$, et al. Exploring design principles of biological and living building envelopes: what can we learn from plant cell walls? Intell Build Int 2018; 10: 78-102.

7. Xing $\mathrm{Y}$, Brewer M, El-Gharabawy $\mathrm{H}$, Griffith $\mathrm{G}$ and Jones $\mathrm{P}$. Growing and testing mycelium bricks as building insulation materials. IOP Conf Ser Earth Environ Sci 2018; 121 (2): 022032. Epub DOI: 10.1088/1755-1315/121/2/022032.

8. Bai Y, Guo R, Xing Y. Relationship between urban heat island and green infrastructure fraction in Harbin. Presented at: SPIE Remote Sensing Technologies and Applications in Urban Environments III, Berlin, 29 October 2018. Published in: Erbertseder T, Chrysoulakis N, Zhang Y (eds) Remote sensing technologies and applications in urban environments III. Vol. 10793. In: Proceedings of SPIE, Bellingham, Washington. SPIE, 2017, pp. 54-66.

9. Kolokotroni M, Shittu E, Santos T, et al. Cool roofs: High tech low cost solution for energy efficiency and thermal comfort in low rise low income houses in high solar radiation countries. Energy Build 2018; 176: 58-70.

10. Santamouris M. Cooling the cities - A review of reflective and green roof mitigation technologies to fight heat island and improve comfort in urban environments. Sol Energy 2014; 103: $682-703$.

11. Gaffin S, Parshall L, O'Keeffe G, et al. Energy balance modeling applied to a comparison of green and white roof cooling efficiency. In: Third annual international greening rooftops for sustainable communities, Green Roof for Healthy Cities. Washington, D.C., May 4-6, 2005.

12. Susca T, Gaffin SR, Dell'Osso GR. Positive effects of vegetation: Urban heat island and green roofs. Environ Pollut 2011; 159: 2119-2126.

13. Sailor DJ. A green roof model for building energy simulation programs. Energy Build 2008; 40: $1466-1478$.

14. Coma J, Pérez G, Solé C, Castell A, Cabeza LF. Thermal assessment of extensive green roofs as passive tool for energy savings in buildings. Renew Energy 2016; 85: 1106-1115.

15. Tabares-Velasco PC, Zhao M, Peterson N, et al. Validation of predictive heat and mass transfer green roof model with extensive green roof field data. Ecol Eng 2012; 47: 165-173. 
Indoor and Built Environment, DOI: 10.1177/1420326X19887218

https://journals.sagepub.com/doi/full/10.1177/1420326X19887218

16. Peri G, Rizzo G, Scaccianoce G, et al. Vegetation and soil - related parameters for computing solar radiation exchanges within green roofs: Are the available values adequate for an easy modeling of their thermal behavior? Energy Build 2016; 129: 535-548.

17. Carson T, Keeley M, Marasco DE, et al. Assessing methods for predicting green roof rainfall capture: A comparison between full-scale observations and four hydrologic models. Urban Water J 2017; 14: 589-603.

18. Schweitzer O, Erell E. Evaluation of the energy performance and irrigation requirements of extensive green roofs in a water-scarce Mediterranean climate. Energy Build 2014; 68: 25-32.

19. Cameron RWF, Taylor JE, Emmett MR. What's 'cool' in the world of green facades? How plant choice influences the cooling properties of green walls. Build Environ 2014; 73: 198-207.

20. Blanusa T, Vaz Monteiro MM, Fantozzi F, et al. Alternatives to Sedum on green roofs: Can broad leaf perennial plants offer better 'cooling service'? Build Environ 2013; 59: 99-106.

21. La Roche P, Berardi U. Comfort and energy savings with active green roofs. Energy Build 2014; 82: 492-504.

22. Kotsiris G, Androutsopoulos A, Polychroni E, et al. Dynamic U-value estimation and energy simulation for green roofs. Energy Build 2012; 45: 240-249.

23. Stovin V, Vesuviano G, Kasmin $\mathrm{H}$. The hydrological performance of a green roof test bed under UK climatic conditions. J Hydrol 2012; 414-415: 148-161.

24. MetOffice. Cardiff Climate, Climate period 1981-2010, https://www.metoffice.gov.uk/public/weather/climate/gcjszevgx (2018).

25. ASHRAE. ASHRAE Handbook Fundamentals. Atlanta: American Society of Heating, Referating and Air-conditioning Engineers, 2005. DOI: 10.1039/c1cs15219j.

26. Bretz S, Akbari H, Rosenfeld A. Practical issues using solar-reflecting materials to mitigate urban heat islands. Atmos Environ 1998; 32: 95-101.

27. Gascoin S, Duchame A, Ribstein P, et al. Sensitivity of bare soil albedo to surface soil moisture on the moraine of the Zongo glacier (Bolivia). Geophys Res Lett 2009; 36: 2-6. 
Indoor and Built Environment, DOI: 10.1177/1420326X19887218

https://journals.sagepub.com/doi/full/10.1177/1420326X19887218

28. Lazzarin RM, Castellotti F, Busato F. Experimental measurements and numerical modelling of a green roof. Energy Build 2005; 37: 1260-1267.

29. Lundholm J, Maclvor JS, MacDougall Z, Ranalli M. Plant species and functional group combinations affect green roof ecosystem functions. PLoS On; 2010; 5(3): e9677. Online epubl. DOI: 10.1371/journal.pone.0009677.

30. Sailor DJ, Hagos M. An updated and expanded set of thermal property data for green roof growing media. Energy Build 2011; 43: 2298-2303.

31. ISO 9869-1:2014, Thermal insulation - building elements - in-situ measurement of thermal resistance and thermal transmittance. International Organization for Standardization, Geneva, 2014.

32. ASTM C1155 - 95(2013). Standard Practice for Determining Thermal Resistance of Building Envelope Components from the In-Situ Data. West Conshohocken, PA, ASTM, 2013.

33. Hukseflux. USER MANUAL HFP01 \& HFP03 Heat flux plate / heat flux sensor. 2015.

34. Johansen O. Thermal Conductivity of Soils, Ph.D. dissertation, Norwegian University of Science and Technology, Trondheim, 1975. DOI: 10.1063/1.1699752.

35. Côté J, Konrad J-M. A generalized thermal conductivity model for soils and construction materials. Can Geotech J 2005; 42: 443-458.

36. Wootton-Beard P, Xing Y, Durai Prabhakaran R, et al. Review: Improving the Impact of Plant Science on Urban Planning and Design. Buildings 2016; 6: 48. 